\title{
EDITORIAL - SPECIAL SECTION IN BIOINFORMATICS
}

Just like its primary object of study - i.e. life-biology is a dynamic and ever changing area. Indeed, since the birth of science in Greece, biology has progressed all the way from empirical thinking into one of the most dynamic research areas, currently involving statistics, mathematics, physics, engineering and computer science, hence the name Bioinformatics.

The First International Conference on Bioinformatics and Computational Biology - I ICoBiCoBi, which took place in Ribeirão Preto from the 14th to 16th May 2003, provided a representative forum for integrating the national community in related areas. Devised by the Bioinformatics PhD programme of the University of São Paulo, the I ICoBiCoBi became a reality thanks to the wholehearted involvement of many individuals and institutions, with special thanks to the Organizing and Program Committees, CAPES, FAPESP, CNPq, Pró-Reitoria de Pós-Graduação - USP and Pró-Reitoria de Pesquisa USP.

This special section of Genetics and Molecular Biology contains a selection of articles presented in "The I ICoBiCoBi," providing a rich sample of representative developments in bioinformatics, from sequencing to systems biology.

Luciano da Fontoura Costa, IFSC-USP Roberto Marcondes Cesar Jr, IME-USP

Junior Barrera, IME-USP 